\title{
Binocular and Monocular Resolution Thresholds throughout Adulthood for Luminance-Modulated and Contrast-Modulated Noise Letters
}

(Nilai Ambang Resolusi Monokular dan Binokular sepanjang Usia Dewasa untuk Stimulus Hingar Termodulasi Luminans dan Kontras)

\author{
PUI JUAN WOI, SHARANJEET-KAUR \& MOHD IZZUDDIN HAIROL**
}

\begin{abstract}
Contrast-modulated (CM) noise stimuli are thought to be processed in higher, more binocular visual areas compared to luminance-modulated (LM) stimuli, and the ability to perceive them may be more susceptible to ageing. The aim of this study was to determine monocular and binocular resolution thresholds for LM and CM noise letters throughout adulthood. Resolution thresholds for LM and CM noise letters were measured in 25 participants (age 21-70 years old) under monocular and binocular viewing. Stimuli were $H, O, T$ and V letters created by adding or multiplying a luminance modulation function to a binary white noise carrier to create LM and CM noise letters, respectively. Resolution thresholds, determined using a 2-down-1-up staircase procedure, were lower for LM, than for CM, stimuli in both monocular and binocular viewing conditions $(p<0.05)$. Binocular summation ratio for CM noise letters was significantly higher than that for LM noise letters $(p<0.05)$ but declined rapidly with increasing age. For the youngest age group (20-29 years old), binocular resolution threshold was 39\% better ( 1.5-line improvement on the clinical letter chart) than monocular resolution threshold for CM noise letters, but only $15 \%$ better ( 0.5-line improvement) when measured with LM noise letters. Binocular performance for CM noise letters declines at a faster rate with increasing age compared to that for LM noise letters. Visual function measurement with contrast-modulated stimuli might be useful to detect subtle binocular vision anomalies that may occur in early adulthood, which may be missed if measured with luminance-based stimuli alone.
\end{abstract}

Keywords: Ageing; binocular resolution; contrast-modulated; luminance-modulated; monocular resolution

ABSTRAK

Rangsangan hingar modulasi kontras (CM) dianggap diproses lebih tinggi, di kawasan yang mempunyai lebih visual binokular berbanding rangsangan modulasi luminans (LM) dan keupayaan untuk mengamatinya mungkin lebih terdedah kepada penuaan. Matlamat kajian ini adalah untuk menentukan ambang resolusi monokular dan binokular untuk huruf hingar LM dan CM sepanjang tempoh dewasa. Ambang resolusi untuk huruf hingar LM dan CM telah diukur pada 25 peserta (umur 21-70 tahun) di bawah penglihatan monokular dan binokular. Rangsangan adalah huruf $H, O, T$ dan $V$ yang dicipta dengan menambah atau mendarabkan fungsi modulasi luminans kepada pembawa bunyi putih untuk mewujudkan huruf hingar LM dan CM. Ambang resolusi ditentukan menggunakan prosedur tangga 2-turun-1-naik, lebih rendah untuk LM berbanding CM untuk rangsangan dalam kedua-dua keadaan pandangan monokular dan binokular ( $p$ $<0.05)$. Nisbah penjumlahan binokular untuk huruf hingar CM adalah jauh lebih tinggi daripada untuk huruf hingar LM $(p<0.05)$ tetapi menurun dengan cepat dengan peningkatan umur. Bagi kumpulan umur bongsu (20-29 tahun), ambang resolusi binokular adalah $39 \%$ lebih baik (peningkatan garisan $\sim 1.5$ dalam carta huruf klinikal) berbanding ambang resolusi monokular untuk huruf hingar CM, tetapi hanya 15\% lebih baik (peningkatan garisan 0.5) apabila diukur dengan huruf hingar LM. Prestasi binokular untuk huruf hingar CM menurun pada kadar yang lebih cepat dengan peningkatan umur berbanding dengan huruf hingar LM. Pengukuran fungsi visual dengan rangsangan modulasi kontras mungkin berguna untuk mengesan anomali visual binokular halus yang mungkin berlaku pada peringkat awal dewasa, yang mungkin terlepas pandang jika diukur dengan berasaskan luminans sahaja.

Kata kunci: Modulasi kontras; modulasi luminans; penuaan; resolusi binokular; resolusi monokular

\section{INTRODUCTION}

Human visual performance reduces with normal ageing, i.e., ageing that is free of pathology or disease. Visual acuity (VA) measurement is a quick yet effective test which provides useful information in routine optometric examination. Previous studies show that VA gradually declines after the age of 50 to 60 (Elliot et al. 1995; Frisen $\&$ Frisen 1981). Contrast sensitivity also reduces in the elderly, even when senile miosis and reduced optical transmission factors are taken into consideration (Elliott et al. 1990). Although VA is relatively spared, stereoacuity in healthy older adults is reduced even without cognitive 
impairment such as Alzheimer's disease (Bassi et al. 1993) implying that deterioration in binocular vision and binocular neurons of the visual cortex occurs later in life.

Visual acuity is usually measured using clinical letter charts, which comprise of black optotypes on a white background, that is, with maximum luminance difference between them. A stimulus whose luminance is different from its background is known as a first-order, luminance-modulated (LM) stimulus. A stimulus which has the same mean luminance as its background, but defined by other variations, such as contrast, texture or orientation, is known as second-order stimuli (Dosher \& Lu 2006; Larsson et al. 2006; Schofield \& Georgeson 2003). It has been suggested that first- and second-order stimuli are processed by different mechanisms within the visual cortex (Baker \& Mareschal, 2001; Chubb \& Sperling 1988). Second-order processing mechanism appears to be generally less sensitive compared to firstorder processing mechanism and thus second-order vision has lower resolution than first-order vision (Schofield \& Georgeson 1999). Cells in area 18 of cats (analogous to primate extrastriate cortex) showed binocular interaction for second-order, contrast-modulated (CM) stimuli (Tanaka \& Ohzawa 2006).

The effect of ageing on perception of CM stimuli has been reported. Contrast sensitivity for CM stimuli of older adults is significantly worse than that for LM stimuli (Habak \& Faubert 2000). Contrast sensitivity for second-order stimuli begins to reduce significantly earlier with age than that for first-order stimuli, but with a slower progression rate (Tang \& Zhou 2009). Recently we showed that reduction of VA with CM noise letters is higher than that with LM noise letters especially when viewed binocularly for healthy older adults above 50 years old compared to younger adults (Woi et al. 2016). These small but significant visual acuity changes in the elderly may be useful in detecting other subtle changes that may occur in this population, particularly in this country's context where a decline in cognitive function (Fun et al. 2016; $\mathrm{Ng}$ 2016) and other visual problems (Mohammed et al. 2016) have been reported. Previous studies have focused on acuity changes throughout adulthood with first-order stimuli, but little is known about how increasing age affects the acuity of second-order, contrast-modulated noise stimuli. This study aimed to determine monocular and binocular resolution thresholds for LM and CM noise letters in healthy and visually normal participants aged between 21 and 70 years old.

\section{MATERIALS AND METHODS}

\section{PARTICIPANTS}

Twenty-five participants aged from 21 to 70 years old were recruited. Participants were divided into five age groups (Table 1). They underwent ocular health examination to ensure that no ocular pathologies or binocular anomalies were present. None of them had any history of systemic diseases or medication with known ocular involvement. All participants wore their best refractive correction, with corrected distance visual acuity of logMAR 0.1 (Snellen 6/7.5) or better for older adults above 51 years old and logMAR 0.0 (Snellen 6/6) or better for younger adults. Approximately one hour of training session was made compulsory before formal data collection began to ensure that participants were familiar with the experiment. Written consent was obtained from all participants before the start of any data collection. The Ethics Committee of Faculty of Health Sciences, Universiti Kebangsaan Malaysia approved the conduct of this research (UKM 1.5.3.5/244/ NN-053-2015).

\section{APPARATUS}

Stimuli were displayed on a computer screen (ViewSonic Professional Series P227f) using a custom-written program in Matlab (Mathworks, Inc) on a Dell Precision T1600 CPU. The stimuli were loaded on to the frame store memory of a VSG graphic card (Cambridge Research Systems) installed in the computer. Monitor calibration and gamma correction procedures were carried out every three to six months by using OptiCal photometer to avoid adjacent pixel nonlinearity (Bertone et al. 2011; Hairol et al. 2013). In every session, the display monitor was turned on for at least $20 \mathrm{~min}$ to stabilise its luminance output before data collection commenced.

\section{STIMULI}

Resolution thresholds for LM and CM noise letters were determined using $\mathrm{H}, \mathrm{O}, \mathrm{T}$, and $\mathrm{V}$ letters derived from the clinically used Sloan letters. The letters were constructed on a $5 \times 5$ template, where each stroke of the letter is one fifth of the letter's size. The LM noise letters (an example is shown in Figure 1(a)) were created by adding a luminance modulation function to a binary white noise carrier. The CM noise letters (an example is shown in Figure 1(b)) were created by multiplying a modulation function with

TABLE 1. Participant age groups

\begin{tabular}{ccc}
\hline Age group (year) & Number of participants & Mean age \pm SE \\
\hline $21-30$ & 5 & $25.4 \pm 1.29$ \\
$31-40$ & 5 & $31.8 \pm 0.37$ \\
$41-50$ & 5 & $47.2 \pm 1.20$ \\
$51-60$ & 5 & $53.8 \pm 1.16$ \\
$61-70$ & 5 & $65.8 \pm 1.83$ \\
\hline
\end{tabular}


a binary white noise carrier (Chung et al. 2006; Hairol \& Waugh 2010; Hairol et al. 2013). The stimuli can be mathematically expressed as:

$$
\begin{aligned}
I(x, y)= & I_{\circ}[1+n N(x, y)+l L(x, y)+ \\
& m n M(x, y) N(x, y)]
\end{aligned}
$$

where $I(x, y)$ is the luminance at position $(x, y) ; I_{\circ}$ is the mean luminance; $n$ is the noise contrast, which was fixed at 0.2 for all experiments; $N(x, y)$ is the binary noise value at position $(x, y)$ of -1 or $1 ; 1$ is the luminance amplitude, which is zero for $\mathrm{CM}$ noise letters; $m$ is the contrast amplitude, which is zero for LM noise letters; $L(x, y)$ is the luminance modulation function, a square wave; and $M(x, y)$ is the contrast modulation, also a square wave. For generation of LM and CM noise stimuli, either $l$ or $m$ was adjusted, respectively, the other being set to zero. Total size of noise matrix was $500 \times 500$ pixels. Noise checks were scaled to the letter size and each letter consisted of 15 noise checks with $0.47 \mathrm{~mm}$ pixel size for one noise check. Noise was presented dynamically throughout the experiment to avoid any luminance artefacts which may occur due to pixel clumping (Smith \& Ledgeway 1997; Sukumar \& Waugh 2007).

\section{LETTER RESOLUTION THRESHOLD}

Letter resolution thresholds were measured using the staircase method with a four spatial alternativeforced-choice (4AFC) paradigm. The two-down, one-up staircase provided threshold estimation at $70.7 \%$ correct (Shen 2013). Participants recorded what they saw by pressing the appropriate keys on the keyboard. After two successive correct responses, the size of the noise letter was reduced by approximately 0.125 logarithmic of the Minimum Angle of Resolution (logMAR). An incorrect response resulted in $0.125 \log$ MAR increase in the letter size, i.e. a reversal of the staircase. There was no time limit for stimulus presentation. Eight reversals of staircase method ended the experimental run, and acuity threshold was estimated using the last six reversals. A run consisted of 30-40 trials. Data from four runs were averaged to obtain the mean acuity threshold. The experiment was

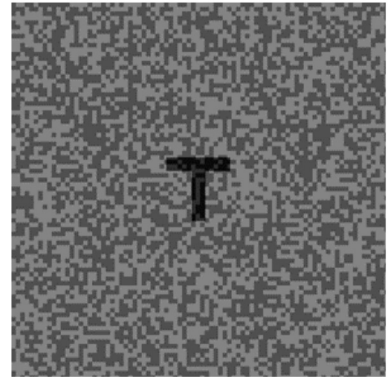

(a)

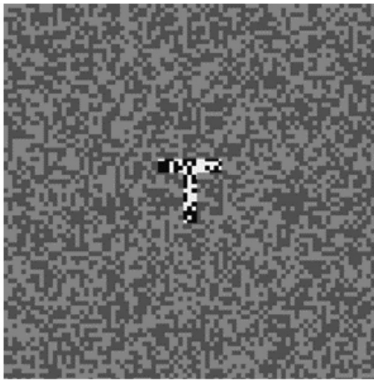

(b)
FIGURE 1. Stimuli: (a) luminance-modulated (LM) noise letter and (b) contrast-modulated (CM) noise letter

run under binocular viewing and monocular viewing. In monocular viewing, the participant's non-dominant eye was occluded with a black patch. The viewing distance between the participant and the display monitor for all experiments was $9 \mathrm{~m}$ for LM noise letters (achieved with a front-surfaced mirror) and $4.5 \mathrm{~m}$ for CM noise letters. The distances were chosen in such a way to enable a full range of letter sizes to appear on display monitor and to allow a perfect match in noise check size (Hairol et al. 2013). Room illumination was kept constant across the testing distance.

\section{RESULTS}

Letter resolution thresholds in logMAR measured with LM and CM noise letters under monocular and binocular viewing are shown in Figure 2. Table 2 shows the threshold values. For LM noise letters, monocular resolution thresholds improved by 0.08 and $0.07 \log$ MAR, respectively, (equivalent to improvement of approximately four letters on the logMAR letter acuity chart) from 21-30 years old to 31-40 years old. Similar findings are found for binocular resolution thresholds for LM noise letters.

For CM noise letters, monocular resolution threshold improved by $0.04 \log$ MAR (two letters) from 21-30 years old to 31-40 years old. However, binocular resolution thresholds with CM noise letters were similar for those in the 21-30 year-old and 31-40 year old age groups. After

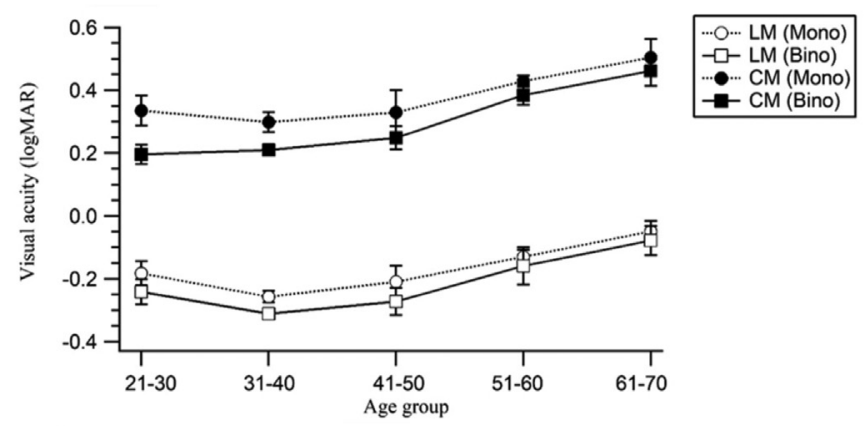

FIGURE 2. VA (logMAR) measured with LM (open symbols) and CM (filled symbols) letters under monocular (circles) and binocular (squares) viewing across five adult age groups 
TABLE 2. Monocular and binocular VA (logMAR) with LM and CM letters for five adult age groups

\begin{tabular}{ccccc}
\hline \multirow{2}{*}{$\begin{array}{c}\text { Age } \\
\text { group }\end{array}$} & \begin{tabular}{c} 
LM noise letters \\
Monocular VA \\
\cline { 2 - 5 }
\end{tabular} & $\begin{array}{c}\text { Binocular VA } \\
(\log M A R \pm S E)\end{array}$ & $\begin{array}{c}\text { Monocular VA } \\
(\log \text { MAR } \pm \text { SE) }\end{array}$ & $\begin{array}{c}\text { Binocular VA } \\
(\log \text { MAR } \pm \text { SE) }\end{array}$ \\
\hline $21-30$ & $-0.18 \pm 0.04$ & $-0.24 \pm 0.04$ & $0.34 \pm 0.05$ & $0.20 \pm 0.03$ \\
$31-40$ & $-0.26 \pm 0.02$ & $-0.31 \pm 0.02$ & $0.30 \pm 0.03$ & $0.21 \pm 0.02$ \\
$41-50$ & $-0.21 \pm 0.05$ & $-0.27 \pm 0.04$ & $0.33 \pm 0.07$ & $0.25 \pm 0.04$ \\
$51-60$ & $-0.13 \pm 0.06$ & $-0.16 \pm 0.06$ & $0.43 \pm 0.02$ & $0.39 \pm 0.03$ \\
$61-70$ & $-0.05 \pm 0.03$ & $-0.08 \pm 0.05$ & $0.50 \pm 0.06$ & $0.46 \pm 0.05$ \\
\hline
\end{tabular}

31-40 years old, resolution thresholds in all conditions gradually declined throughout the age range.

A three-factor mixed model analysis of variance (ANOVA) showed that resolution thresholds measured with LM noise letters were significantly lower than resolution thresholds with $\mathrm{CM}$ noise letters $\left[\mathrm{F}_{(1,20)}=2121.44, p\right.$ $<0.001]$. Binocular resolution thresholds were lower than monocular resolution thresholds $\left[\mathrm{F}_{(1,20)}=28.51\right.$, $p<0.001]$. There was a significant main effect of age group on letter resolution thresholds $\left[\mathrm{F}_{(4,20)}=6.15, p<\right.$ $0.05]$. A Tukey post hoc test showed that letter resolution thresholds for 61-70 years old, the eldest age group, was significantly higher compared to 21-30 ( $p<0.05)$, 31$40(p<0.05)$ and $41-50$ age group $(p<0.05)$, but there was no significant difference compared to the 51-60 age group $(p>0.05)$. This suggests that rate of resolution threshold decline decreases by the fifth decade. There was no statistically significant interaction between stimulus type, viewing condition and age on letter resolution thresholds $\left[\mathrm{F}_{4,20)}=0.643, p>0.05\right]$, that is, the change in resolution threshold for the two stimulus types under the two viewing conditions were similar across the tested age groups.

Figure 3 shows binocular summation ratios, defined as the ratio between monocular resolution threshold and binocular resolution threshold (both in units of MAR) for LM and CM noise letters. Table 3 shows the binocular summation ratio values. Overall, binocular summation ratio for $\mathrm{CM}$ noise letters was significantly higher than that for LM noise letters $\left[\mathrm{F}_{(1,4)}=4.88, p<0.05\right]$, but there was no main significant effect of age on binocular summation ratio $\left[\mathrm{F}_{(4,20)}=1.083, p>0.05\right]$. Binocular summation ratio for $\mathrm{CM}$ noise letters declined rapidly with increasing age, compared to that for LM noise stimuli, as shown in Figure 3 . For the youngest age group (21-30 years old), binocular resolution threshold was $39 \%$ better than monocular resolution threshold for CM noise letters, but only $15 \%$ better when measured with LM noise letters.

\section{DISCUSSION}

We have shown that resolution thresholds for luminancemodulated and contrast-modulated noise letters declined in adults above 50 years old compared to younger adults (Woi et al. 2016). However, the pattern of change across age groups and the differences between monocular and binocular acuities remained unclear. As it has been suggested that $\mathrm{CM}$ stimuli processing involve responses from a higher, more binocular visual areas than those for LM stimuli (Calvert et al. 2005; Ellemberg et al. 2003; Hairol \& Waugh 2010; Wong et al. 2005) and that visual areas higher than V1 are more susceptible to decline with increasing age and to age-associated cognitive impairment (Brewer \& Barton 2014; Crossland et al. 2008), the results of this study will add to our understanding on how normal ageing affects perception of LM and CM noise stimuli.

In this study, monocular and binocular resolution thresholds for LM and CM letters across adult age groups were measured. For all adult age groups, resolution thresholds with LM letters were better than that with

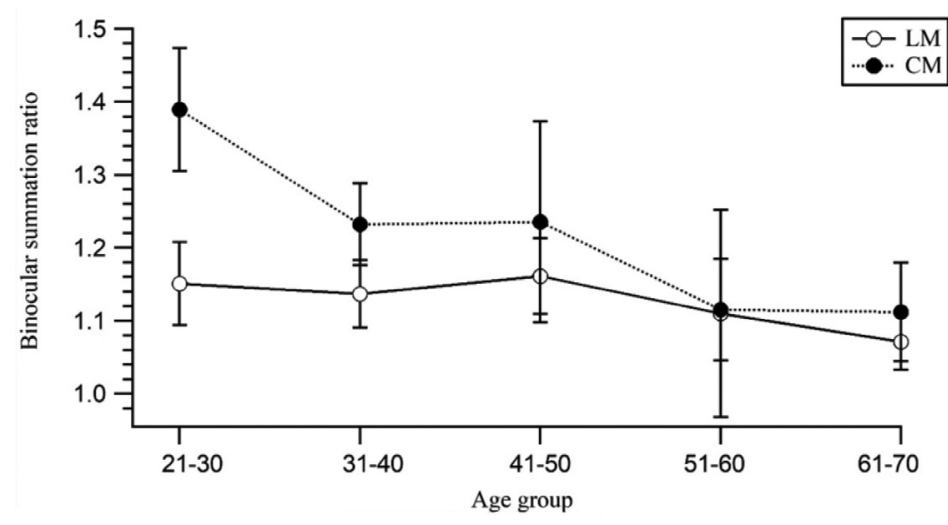

FIGURE 3. Binocular summation ratio for LM and CM letters across five adult age groups 
TABLE 3. Binocular summation ratios with LM and CM letters for five adult age groups

\begin{tabular}{lccccc}
\hline & \multicolumn{5}{c}{ Age group } \\
\cline { 2 - 5 } & $21-30$ & $31-40$ & $41-50$ & $51-60$ & $61-70$ \\
\hline LM noise letters & $1.15 \pm 0.06$ & $1.14 \pm 0.05$ & $1.16 \pm 0.05$ & $1.11 \pm 0.14$ & $1.07 \pm 0.04$ \\
CM noise letters & $1.39 \pm 0.08$ & $1.23 \pm 0.06$ & $1.24 \pm 0.14$ & $1.12 \pm 0.07$ & $1.11 \pm 0.07$ \\
\hline
\end{tabular}

$\mathrm{CM}$ letters. Earlier studies have reported that resolution thresholds for LM stimuli were better than that for CM stimuli in normal young adults (Hairol et al. 2013; Waugh et al.2010). These results support the suggestion that larger spatial processing mechanisms are needed for CM stimuli compared to LM stimuli (Schofield \& Georgeson 1999nonFourier modulations of image contrast. Models for secondorder motion have suggested two filtering stages separated by a rectifying nonlinearity. We explore here the encoding of stationary first-order and second-order gratings, and their interaction. Stimuli consisted of 2-D binary, broad-band, static, visual noise sinusoidally modulated in luminance (LM, first-order; Schofield \& Georgeson 2003), indicating that $\mathrm{CM}$ stimuli processing may involve visual areas with larger receptive fields than that for LM stimuli processing. Indeed, previous fMRI study on humans (Smith et al. 2001) showed larger receptive fields in V2 and higher visual areas, than the receptive fields in V1.

We found that, in the 21-30 age group, binocular viewing improved resolution thresholds of CM noise letter by $33 \%$, and resolution of LM letters improved by $15 \%$. Clinically, this translates as binocular viewing improves $\mathrm{CM}$ letter resolution by about seven letters (improvement of more than a line on the $\log$ MAR letter chart) while it only improves LM letter resolution by about three letters (about half a line on the logMAR letter chart). The difference in binocular resolution threshold improvement between LM and $\mathrm{CM}$ noise letters are of clinical significance which suggests that binocularity provides an advantage during early adulthood when a CM (or second-order) stimulus is involved in a visual task. It also suggests the advantage of binocularity in improving resolution thresholds measured with CM noise letters in young adults, and this advantage diminishes as age increases. As CM stimulus processing has been suggested to involve higher, more binocular visual areas (Calvert et al. 2005; Hairol \& Waugh 2010; Wong et al. 2005), reduction in binocular summation ratio for CM stimuli with increasing age may be related to earlier findings that ageing have a more pronounced effect in visual areas higher than the primary striate cortex (Bertone et al. 2011; Costa et al. 2013; Tang \& Zhou 2009). The lower CM binocular summation ratio in our healthy elder age group could reflect the effect of healthy ageing on human primary visual cortex (V1) and visual areas beyond V1 (Brewer \& Barton 2014, 2012).

\section{CONCLUSION}

Binocular resolution thresholds are lower than monocular resolution thresholds for both $\mathrm{LM}$ and $\mathrm{CM}$ letters. The difference between thresholds between these two viewing conditions iss greatest for $\mathrm{CM}$ noise letters in youngest adult group. However, binocular performance for $\mathrm{CM}$ noise letters declines at a faster rate with increasing age compared to that for LM noise letters. Visual function measurement with contrast-based stimuli may be useful to detect subtle binocular vision anomalies that may occur in the early adulthood, which may be missed if measured with luminance-based stimuli alone.

\section{ACKNOWLEDGEMENTS}

The project and the first author (Woi Pui Juan) were funded by the Geran Universiti Penyelidikan (GUP-2016-049) from Universiti Kebangsaan Malaysia.

\section{REFERENCES}

Baker, C.L. \& Mareschal, I. 2001. Processing of second-order stimuli in the visual cortex. Progress in Brain Research 134: 171-191.

Bassi, C.J., Solomon, K. \& Young, D. 1993. Vision in aging and dementia. Optometry and Vision Science 70(10): 809-813.

Bertone, A., Guy, J. \& Faubert, J. 2011. Assessing spatial perception in aging using an adapted Landolt-C technique. Neuroreport 22: 951-955.

Brewer, A.A. \& Barton, B. 2012. Effects of healthy aging on human primary visual cortex. Health 4(9A): 695-702.

Brewer, A. \& Barton, B. 2014. Visual cortex in aging and Alzheimer's disease: Changes in visual field maps and population receptive fields. Frontiers in Psychology. https:// www.frontiersin.org/article/10.3389/fpsyg.2014.00074.

Calvert, J., Manahilov, V., Simpson, W.A. \& Parker, D.M. 2005. Human cortical responses to contrast modulations of visual noise. Vision Research 45(17): 2218-2230.

Chubb, C. \& Sperling, G. 1988. Drift-balanced random stimuli: A general basis for studying non-Fourier motion perception. J. Opt. Soc. Am. 5(11): 1986-2007.

Chung, S.T.L., Li, R.W. \& Levi, D.M. 2006. Identification of contrast-defined letters benefits from perceptual learning in adults with amblyopia. Vision Research 46(22): 3853-3861.

Costa, T.L., Nogueira, R.M.T.B.L., Pereira, A.G.F. \& Santos, N.A. 2013. Differential effects of aging on spatial contrast sensitivity to linear and polar sine-wave gratings. Brazilian Journal of Medical and Biological Research 46(10): 855-860.

Crossland, M.D., Morland, A.B., Feely, M.P., Von Dem Hagen, E. \& Rubin, G.S. 2008. The effect of age and fixation instability on retinotopic mapping of primary visual cortex. Investigative Ophthalmology and Visual Science 49: 3734-3739.

Dosher, B.A. \& Lu, Z.L. 2006. Level and mechanisms of perceptual learning: Learning first-order luminance and second-order texture objects. Vision Research 46(12): 19962007. 
Ellemberg, D., Lavoie, K., Lewis, T.L., Maurer, D., Lepore, F. \& Guillemot, J.P. 2003. Longer VEP latencies and slower reaction times to the onset of second-order motion than to the onset of first-order motion. Vision Research. http://doi. org/10.1016/S0042-6989(03)00006-3.

Elliot, D.B., Yang, K.C.H. \& Whitaker, D. 1995. Visual acuity changes throughout adulthood in normal, healthy eyes: Seeing beyond 6/6. Optometry and Vision Science 72(3): 186-191.

Elliott, D.B., Whitaker, D. \& Bonette, L. 1990. Differences in the legibility of letters at contrast threshold using the PelliRobson chart. Ophthalmic and Physiological Optics 10(4): 323-326.

Frisen, L. \& Frisen, M. 1981. How good is normal visual acuity? A study of letter acuity thresholds as a function of age. Albrecht Yon Graefes Arch Klin. Ophthalmol. 215: 149-157.

Fun, S.P., Mohidin, N., Kamal, A.A.M., Mohammed, Z. \& MohdAli, B. 2016. Mild cognitive impairment does not affect pattern electroretinogram in the elderly-a pilot study. Sains Malaysiana 45(9): 1399-1403.

Habak, C. \& Faubert, J. 2000. Larger effect of aging on the perception of higher-order stimuli. Vision Research 40(2000): 943-950.

Hairol, M.I., Formankiewicz, M. \& Waugh, S.J. 2013. Foveal visual acuity is worse and shows stronger contour interaction effects for contrast-modulated than luminance-modulated Cs. Visual Neuroscience 30: 105-120.

Hairol, M.I. \& Waugh, S.J. 2010. Lateral facilitation revealed dichoptically for luminance-modulated and contrastmodulated stimuli. Vision Research 50(23): 2530-2542.

Larsson, J., Landy, M.S. \& Heeger, D.J. 2006. Orientationselective adaptation to first- and second-order patterns in human visual cortex. Journal of Neurophysiology 95: 862881.

Mohammed, Z., Mansor, S.Z. \& Mohamed Akhir, S. 2016. Refractive error and visual acuity of elderly Chinese in Selangor and Johor, Malaysia. Sains Malaysiana 45(9): 1393-1398.

Ng, T.P. 2016. Cognitive health of older persons in longitudinal ageing cohort studies. Sains Malaysiana 45(9): 1351-1355.

Schofield, A.J. \& Georgeson, M.A. 1999. Sensitivity to modulations of luminance and contrast in visual white noise: Separate mechanisms with similar behaviour. Vision Research 39(16): 2697-2716.

Schofield, A.J. \& Georgeson, M.A. 2003. Sensitivity to contrast modulation: The spatial frequency dependence of secondorder vision. Vision Research 43: 243-259.

Shen, Y. 2013. Comparing adaptive procedures for estimating the psychometric function for an auditory gap detection task. Atten Percept. Psychophys. 75(4): 771-780.
Smith, A.T. \& Ledgeway, T. 1997. Separate detection of moving luminance and contrast modulations: Fact or Artifact ? Vision Research 37(1): 45-62.

Sukumar, S. \& Waugh, S.J. 2007. Separate first- and second-order processing is supported by spatial summation estimates at the fovea and eccentrically. Vision Research 47: 581-596.

Tanaka, H. \& Ohzawa, I. 2006. Neural basis for stereopsis from second-order contrast cues. Journal of Neuroscience 26(16): 4370-4382.

Tang, Y. \& Zhou, Y. 2009. Age-related decline of contrast sensitivity for second-order stimuli: Earlier onset, but slower progression, than for first-order stimuli. Journal of Vision 9: 18.

Waugh, S.J., Formankiewicz, M.A., Ahmad, N. \& Hairol, M.I. 2010. Effects of dioptric blur on foveal acuity and contour interaction for noisy Cs. Journal of Vision 10(7): 1330.

Woi, P.J., Kaur, S., Waugh, S.J. \& Hairol, M.I. 2016. Visual acuity measured with luminance-modulated and contrast-modulated letter stimuli in young adults and adults above 50 years old. F1000Research 5: 1961.

Wong, E.H., Levi, D.M. \& McGraw, P.V. 2005. Spatial interactions reveal inhibitory cortical networks in human amblyopia. Vision Research 45(21): 2810-2819.

Optometry \& Vision Science Programme

Centre for Community Health

Faculty of Health Sciences

Universiti Kebangsaan Malaysia

Jalan Raja Muda Abdul Aziz

50300 Kuala Lumpur, Federal Territory

Malaysia

*Corresponding author; email: izzuddin.hairol@ukm.edu.my

Received: 7 October 2018

Accepted: 20 September 2019 